\title{
STRUKTUR KESUCIAN, HIJRAH DAN RUANG QUEER: ANALISA TERHADAP PERILAKU MAHASISWA BERCADAR
}

\section{STUCTURE OF PURENESS, CULTURAL SHIFTING AND SPACE QUEER: ANALYSIS OF VEILED STUDENT BEHAVIOUR}

\author{
Munawar Ahmad', Ustadi Hamzah², Singgih Basuki², Siswanto Masruri², Hayadin ${ }^{3}$ \\ ${ }^{1}$ Prodi Sosiologi Agama Fakultas Ushuluddin UIN Sunan Kalijaga Yogyakarta \\ ${ }^{2}$ Prodi Studi Agama-agama Fakultas Ushuluddin UIN Sunan Kalijaga \\ ${ }^{3}$ Puslitbang Pendidikan Agama dan Keagamaan \\ Email: munawar.ahmad@uin-suka.ac.id
}

Naskah Diterima: 22 Februari 2019; Direvisi: 13 Maret 2019; Disetujui: 24 Oktober 2019

\begin{abstract}
This article aims to explain the case of female college students who use the veil in the college campus area, and deal with the prohibition of the college leadership. The study uses qualitative methods, conducted in 2018 at several state Islamic universities (UIN) in the regions of Java, Sumatra, Kalimantan and Sulawesi. The data source comes from observations and interviews with female veil users. Data collection uses in-depth interview techniques, and snow-ball. Triangulation is carried out to strengthen the validity of the data and information obtained. Analysis of data and facts in the field was developed based on the theory of chastity structure developed from the structure of feeling structure (structure of feeling). The results showed that the female student's veil dressing behavior was driven by a changing spirit or moving to be or feel holy. They cannot compromise with campus rules, because they cannot separate private and public spaces. They have a unique logic of space, which is all space as a place of sharia enforcement.
\end{abstract}

Keywords: Cultural shifting; Space-queer; Structure of pureness; Veil

\begin{abstract}
Abstrak
Artikel ini bertujuan untuk menjelaskan kasus mahasiswi yang menggunakan cadar di wilayah kampus perguruan tinggi, dan berhadapan dengan larangan Pimpinan perguruan tinggi tersebut. Penelitian menggunakan metode kualitatif, dilakukan pada tahun 2018 pada beberapa Universitas Islam Negeri (UIN) di wilayah Jawa, Sumatera, Kalimantan dan Sulawesi. Sumber data berasal dari observasi dan wawancara pada mahasiswi pengguna cadar. Pengumpulan data menggunakan teknik wawancara mendalam, dan snow-ball. Triangulasi dilakukan untuk memperkuat keabsahan data dan informasi yang diperoleh. Analisa terhadap data dan fakta di lapangan dikembangkan berdasarkan teori struktur kesucian yang dikembangkan dari teori struktur perasaan (structure of feeling). Hasil penelitian menunjukkan bahwa perilaku berpakaian cadar mahasiswi didorong oleh semangat berubah atau hijrah untuk menjadi atau merasa suci. Mereka tidak dapat berkompromi dengan aturan kampus, karena tidak dapat memilah antara ruang privat dan ruang publik. Mereka memiliki logika ruang yang unik, yakni semua ruang sebagai tempat penegakan syariah.
\end{abstract}

Kata Kunci: Hijrah; Kesesuaian ruang; Struktur kesucian; Cadar 


\section{PENDAHULUAN}

Fenomena mahasiswa bercadar di perguruan tinggi, akhir-akhir ini semakin merebak, banyak mahasiswi mengenakan cadar secara terbuka pada saat perkuliahan, hal mana fenomena ini tidak sesuai dengan aturan kampus yang menyatakan selama proses belajar mengajar, mahasiswa harus berpakaian sopan mengikuti peraturan keumuman berpakaian sopan dalam budaya Indonesia. Meskipun berpakaian cadar juga merupakan bagian dari cara berpakaian yang sopan dan tertutup, namun budaya berpakaian di Indonesia memandang pakaian cadar adalah pakaian khusus beribadah bukan pakaian yang umum dipakai dalam kegiatan formal belajar, seperti halnya mengenakan sarung dan peci bagi laki-laki ke kampus, merupakan bentuk berpakaian yang tidak biasa dilakukan selama proses belajar di kampus publik, selain pesantren.

Masalah cadar ternyata mengundang perhatian menarik para ilmuwan, baik antropologi, sosiologi bahwa politik. Cadar dan hijab tidak sekedar dipandang sebagai nilai yang mampu membentuk opini (Todd, 1998), tetapi juga sebagai simbol perlawanan (MacLeod, 1992). Sedangkan beberapa kajian lain terfokus pada pembahasan mengenai posisi cadar pada pakaian perempuan, relasi sosial perempuan berhijab, dan fungsi-fungsi sosial hijab (Abraham, 2007); (Furseth, 2019); (Gould, 2014).

Fenomena hijab di Indonesia secara historis, meskipun dalam jumlah terbatas, sudah dikenakan oleh perempuan muslim sejak era 1980-an. Untuk era berikutnya, tahun 1990an, fenomena hijab (atau dalam penyebutan di Indonesia dengan jilbab) sangat meluas, terutama di kota-kota besar. Munculnya spiritualitas baru pada kalangan kelas menengah, terutama public figure seperti artis nasional, di Indonesia mempengaruhi "citra" jilbab. Momentum ini memberi pengaruh yang besar perkembangan jilbab pada era tahun 2000-an. Hal ini dapat dilihat dari berkembangnya industri fashion khususnya jilbab di kota-kota besar di Indonesia (Gould, 2014).

Fakta tersebut, terbentuk apa yang disebut Piere Boudieau akibat dari habitus begitu dominan memengaruhi cara berpikir dan bertindak manusia (Bourdieu, 1977). Habitus merupakan sebuah konteks sosial dan budaya masyarakat manusia yang "mengendalikan" kesadaran untuk bertindak. Era tahun 1900an sampai 2000-an adalah "fenomena historis" yang memberi "warna" pada habitus masyarakat Indonesia terkait dengan fenomena jilbab. Fenomena jilbab berkembang pesat, sehingga model dan cara penamaannya pun juga berkembang, misalnya hijab dan cadar. Cadar yang dalam konteks masyarakat Indonesia merupakan istilah untuk menyebut pakaian besar yang menutup badan perempuan dan menutup muka. Dewasa ini berkembang pula model dan tata cara berpakaian hijab dengan kelengkapan penutup wajah kecuali mata, yang lazim disebut dengan cadar. Perkembangan itu merupakan "enrichment" dari model dan tata cara berpakaian sebagian perempuan Indonesia berdasarkan habitus yang melatarbelakanginya. (Todd, 1998).

Dewasa ini fenomena perempuan yang bercadar berkembang pula pada kampuskampus di Indonesia. Fenomena ini menjadi perhatian dari berbagai pihak, baik dari akademisi ataupun pemangku kebijakan. Aspek-aspek yang dibahas para pemerhati tersebut meliputi motivasi, strategi adaptasi, dan tanggapan masyarakat (Cahyaningrum and Desiningrum, 2017). Meskipun didasarkan pada persoalan "persepsi" tentang tindakan kekerasan dan organisasi tertentu yang melakukan aktivitas-aktivitas berbeda dengan penampilan perempuan bercadar di Mesir (MacLeod, 1992), di Canada (Khosrojerdi, 2015) (Todd, 1998) dan Amerika (Shin, 2015).

Isu cadar di Indonesia menjadi viral pada bulan Maret 2018, dipicu oleh kasus di Institut Agama Islam Negeri (IAIN) Bukit Tinggi dan universitas Islam negeri (UIN) Yogyakarta. Di Universitas Islam Negeri (UIN) Sunan Kalijaga ada keputusan rektorat untuk membina mahasiswa bercadar, yang kemudian dicabut dengan alasan untuk menjaga iklim akademik yang kondusif. Sejak kejadian tersebut, kasus cadar menjadi viral di media sosial dan menimbulkan keributan terhadap pengguna cadar di kampus, seperti di IAIN Bukittinggi, dan UIN Sunan Kalijaga.

Kasus pelarangan cadar pernah terjadi jauh sebelumnya, seperti kasus dua mahasiswi kedokteran di Universitas Sumatera Utara 
pernah mendapat masalah di kampusnya karena mengenakan cadar pada November 1999 silam. Mereka kerap diusir dari kelas hingga mendapat ancaman tidak diberi nilai jika tetap mengenakan cadar. Hal ini menyusul dekan fakultas kedokteran yang mengeluarkan surat keputusan, di antaranya berisi larangan mengenakan cadar. Perlakuan ini memicu demonstrasi oleh ratusan mahasiswa di Sumatera Utara yang menganggap pelarangan mengenakan cadar bukanlah hal yang tepat dilakukan.

Berkembangnya streo-typing terhadap cadar, sebagai bagian dari terorisme, mengakibatkan fenomena cadar menjadi kontroversial di Indonesia. Hal tersebut diperparah dengan ditangkapnya beberapa wanita bercadar dalam gerakan melawan terorisme. Streo-typing tersebut semakin menyudutkan para pemakai cadar. Selanjutnya, para mahasiswi bercadar melakukan perlawanan terhadap aturan di kampus, dengan menyiasatinya melalui pemakaian masker. Masker dalam logika kampus merupakan simbol dari kesehatan, sedangkan dalam logika pemakai cadar, masker adalah pengganti cadar. Penelitian ini mengungkap alasan para mahasiswi memilih memakai pakaian hijab atau cadar, dan alasan dibalik kegigihan mereka mempertahankan pakaian hijabnya di kampus meskipun dilarang oleh pimpinan perguruan tinggi.

\section{Kajian Pustaka}

Secara normatif pakaian yang menutup badan disebut dengan hijab, namun kata ini dapat bermakna sangat beragam tergantung konteks pemakaiannya. Oleh karena itu, Alquran menyebutnya dengan jilbab. Kata jilbab secara spesifik mengacu pada kain yang berfungi sebagai penutup kepala dan dijulurkan ke bawah sehingga menutup leher dan dada perempuan. Para pengkaji Barat lazim menyebutnya sebagai hijab, dan jarang menggunakan istilah jilbab (Shirazi, 2001) (Haddad, 2019) Haddad, 2007).

Ajaran Islam tidak menyebutkan secara tegas bagaimana bentuk, warna, dan model dari penutup kepala dan badan bagi perempuan. Dalam Alquran istilah yang digunakan adalah jilbâb yang disebutkan dalam bentuk jamak jalâbîb. Aspek yang ditegaskan dalam ajaran
Islam adalah fungsi dari jilbâb itu sendiri, yakni menutup kepala, leher, dan badannya termasuk dada. Jilbâb merupakan pakaian dan cara berpakaian sebagaimana disebutkan dalam Q.S. al-Ahzâb [33]: 59; al-Nûr [24]: 31 di atas, yakni kain longgar, tebal, dan tidak transparan yang mampu menutupi seluruh anggota badan perempuan termasuk leher dan dada (juyûb), kecuali telapak tangan dan wajah pada saat keluar rumah.

Dalam bahasa sehari-hari muncul istilah-istilah jilbâb, hijâb, khumûr, syailah, burqa, niqâb, abaya, chador (cadar), pardeh (purdah), makromah, dan charshaf. Namanama itu merupakan bentuk ungkapan kebahasaan dan cara pemakaian jilbab yang berbeda-beda di wilayah-wilayah muslim. Kata chador (cadar) adalah jilbab di Iran yang menutup seluruh tubuh kecuali mata, abaya adalah jilbab di Iraq yang merupakan kain kerudung besar yang menjulur menutup kepala, dada, dan sebagian besar badan. Istilah ini serupa dengan pardeh (purdah) di India. Charshaf adalah pakaian besar yang menutup kepala dan badan yang dibalut dengan jaket panjang besar yang lazim dipakai oleh perempuan muslimah Turki dan wilayah Balkan lainnya. Cara berpakaian "berjilbab" tersebut sama dengan istilah hijab di Mesir, Yaman, Sudan, dan wilayah muslim di Afrika. Hal serupa juga searti dengan burqa dan niqab. Adapun istilah khumur (khimar) merupakan kain penutup kepala saja yang searti dengan tradisi perempuan Indonesia tahun 1970-1980an yang disebut makromah, sedangkan syailah adalah kain yang digunakan untuk menutup sebagian anggota badan bagian atas, dan biasanya disamakan dengan khimar (khumur).

Di antara kajian-kajian yang pernah dilakukan tersebut di antaranya dilakukan oleh Iskandar (2013). Dalam penelitian ini peneliti menguraikan bagaimana muslimah bercadar melakukan "adaptasi" untuk menunjukkan identitasnya. Melalui teori-teori sosiologi, peneliti menganalisis konstruksi sosial bagi para muslimah bercadar tersebut. Penelitian ini belum secara spesifik membahas mengenai motivasi, afiliasi, pemahaman keagamaan, dan wawasan kebangsaan para muslimah bercadar tersebut. Penelitian lain dilakukan oleh F. Yurika Wardhani pada tentang penyesuaian diri 
pada pernikahan bagi muslimah berhijab dan bercadar (Wardhani, 2008). Teori-teori psikologi diaplikasikan oleh peneliti untuk menganalisis bagaimana strategi adaptasi muslimah berhijab dan bercadar pada pernikahan yang dilakukan.

Penelitian lain yang telah dilakukan adalah "Cadar, Media, dan Identitas Perempuan Muslim” (Ratri, 2011). Pada penelitian ini dikaji bagaimana media memersepsikan identitas perempuan bercadar dalam kehidupan sosial mereka. Dengan mengaplikasikan teoriteori sosiologi dan media studies, peneliti menguraikan persoalan tersebut. Penelitian berikutnya dilakukan oleh mahasiswa universitas Islam Jakarta (Susanti, 2008). Beliau menyoroti bagaimana mahasiswi yang mengenakan cadar berinteraksi dengan mahasiswi lainnya, dan bagaimana pola penyesuaian diri dengan mahasiswi lainnya.

Kemudian penelitian yang dilakukan oleh Aulia (2013), tentang budaya wanita pada masyarakat Bima yang menggunakan pakaian bernama RIMPU yang mirip dengan cadar. Rimpu bagi kaum wanita di Bima dibedakan sesuai status. Bagi gadis, memakai Rimpu Mpida. Ini sama saja dengan penggunaan cadar pada kaum wanita muslim. Caranya, sarung yang ada dililit mengikuti arah kepala dan muka kemudian menyisakan ruang terbuka pada bagian mata. Sedangkan bagi kaum wanita yang telah bersuami memakai Rimpu Colo. Dimana bagian muka semua terbuka. Caranya pun hampir sama.

Penelitian lain yang masih fokus pada kajian tentang cadar berjudul "Cadar Wanita dalam Perspektif Alquran" (Fithrotin, 2017) Dalam penelitian ini dianalisis bagaimana ayatayat Alqur'n menggambarkan cadar bagi perempuan. Berbasis pada kajian Quranic Studies, analisis yang dilakukan oleh Fithrotin fokus pada perspektif Alquran mengenai cadar. Penelitian ini belum fokus menggambarkan bagaimana motivasi, afiliasi, pemahaman keagamaan, dan wawasan kebangsaan para muslimah bercadar tersebut.

Kajian tentang bagaimana pakaian perempuan juga dilakukan oleh sarjana-sarjana Barat. Mereka tidak spesifik mengulas persoalan cadar, tetapi lebih umum mengenai hijab, purdah, dan niqab. Tema-tema yang diangkat juga berkisar pada resistensi dan pelarangan hijab, strategi adaptasi, dan bagaimana hijab menjadi ikon dalam lifestyle muslimah di Barat. Di antara karya-karya tersebut berjudul "Hijab" and American Muslim Women: Creating the Space for Autonomous Selves" yang dilakukan oleh Rhys H. Williams dan Gira Vashi (Williams and Vashi, 2007) . Kedua peneliti fokus pada kajian mengenai bagaimana perempuan muslim berhijab di Amerika menempatkan diri dalam konteks kehidupan sosialnya. Secara spesifik kajian ini belum membahas tentang motivasi, afiliasi, pemahaman keagamaan, dan wawasan kebangsaan para muslimah bercadar tersebut.

Tulisan Rhys Williams dan Gira Vashi merupakan respons atas tulisan Ashraf (Zahedi, 2007), dan Rebecca (Gould, 2014), yang mengulas secara spesifik tentang bagaimana makna hijab dalam kontestasi politik di Iran. Hijab merupakan identitas bagi perempuan di Iran sehingga hal itu "diperhitungkan" dalam konteks politik di Iran. Hal ini berlainan dengan konteks di Eropa, khususnya di Swiss. Di negara ini perempuan berhijab (burqa) menjadi "identitas" yang harus dilarang, dan pelarangan tersebut terstruktur melalui lembaga resmi negara. Hal yang serupa juga terjadi di Mesir, di mana kaum berjilbab melakukan akomodasi kepentingan penguasa tentang identitas dirinya, melalui fashion (MacLeod, 1992).

Dari berbagai kajian yang sudah dilakukan tersebut, tulisan ini berupaya menguraikan fenomena cadar di Indonesia dengan pendekatan teori Dramaturgi dari Irving Goffman dan Structure of Feeling. Teori Structure of Feeling (dorongan mentalitas terdalam), mengacu pada suatu kondisi sosial di mana penggerak dari semua kondisi tersebut adalah suatu dorongan mentalitas yang disebut Raymond Wiliam sebagai feeling (Prendergast and Ebrary, 1995) atau atmospherics, moods, manners, ttitudes, orientations, and so on - an attention that might be of interest to affect theorists with the study of the materiality of the designed world. Sedangkan Froust (2015), menyatakan sebagai berikut:

Feelings constitute the sensitive part of predictive and retrospective processes of onconceptual evaluation of one's own and others'well-being and actions. Being 
essentially evaluative, feelings are always the output of a comparator:in other terms, they are crucial monitoring ingredients in self-regulated adaptive control systems. In such systems, the specific function of a feeling consists in detecting how much a current observed value of a parameter deviates from its expected value, on one or several dimensions relevant to survival.

Bagi William (1977) struktur rasa menjadi dasar dari budaya, yang menggerakkan semua aktivitas sosial, politik dan budaya itu sendiri. Baginya, di dalam budaya terdapat meaning yang terstruktur secara kokoh, dibangun oleh ide dan dorongan-dorongan.

Berdasarkan William (1977), dan Frost (2015), dalam kajian ini istilah feeling diganti dengan pureness yakni dorongan ingin suci, bersih dari dosa. Dengan kata lain, dorongan ingin suci (pureness) merupakan bagian dari struktur kesadaran manusia seperti halnya dorongan-dorongan dasar lainnya. Secara mekanistik, dorongan ini bekerja dalam struktur kesadaran terbawah bagi setiap perilaku dan perubahannya. Struktur pureness ini bekerja melalui pertumbuhan dan berubahan cara hidup, sebagaimana dinyatakan oleh Raymond, growing assertion of a whole way of life, not only as a scale of integrity, but as a mode of interpreting all our common experience, and, in this new interpretation, changing it (William, 1960). Pendapat serupa dietujui oleh ilmuwan sosial lainnya (Prendergast and Ebrary, 1995).

Mekanisme perubahan ini menjadi salah satu aspek yang menjadi perhatian dalam menganalisa fenomena mahasiswa bercadar, berdasarkan pendekatan etnography terhadap pemakai cadar. Terbangunan kesadaran untuk hijrah dari perilaku sebelumnya yang dianggap buruk dan penuh dosa dengan memilih cadar sebagai simbol menjadi suci (puring), menjadikan para pemakai cadar berani menghadapi tekanan dan tantangan dari lingkungan yang tidak bersahabat dengan cadar, salah satunya peraturan berpakaian di kampus.

\section{METODOLOGI}

Penelitian ini menggunakan metodologi kualitatif terhadap fakta antropologi sosial guna menjelaskan akar dari fenomena para pemakai cadar di Indonesia. Data dikumpulkan dengan teknik observasi pada Perguruan Tinggi Keagamaan Islam Negeri (PTKIN) dan wawancara kepada mahasiswi yang menggunakan hijab. Pendekatan snowball dan triangulasi dilakukan untuk memperkuat validitas data dan informasi. Data dan informasi yang diperoleh dideskripsikan dalam catatan dan jurnal harian. Analisa data dilakukan secara deskriptif. Nama dan identitas informan yang disebutkan dalam tulisan ini disamarkan untuk menjunjung tinggi etika penelitian.

\section{HASIL DAN PEMBAHASAN}

Data dan informasi yang diperoleh di lapangan, menggambarkan dengan jelas tentang motif, atau alasan para mahasiswi memilih memakai pakaian hijab atau cadar meskipun dilarang oleh pimpinan perguruan tinggi.

\section{Alasan Bercadar}

Seorang mahasiswi di UIN Surabaya bernama Wati, memberi pengantar yang lebih tegas sebagai alasan mengapa dia kemudian memilih bercadar yakni untuk membentengi perilakunya dari pengaruh negatif lingkungan remaja di sekitarnya. "Dunia remaja itu zona berbahaya, karena kurang baik/kurang sejalan dengan syariah".

Sebagai seorang remaja berusia 19 tahun, Wati merupakan mahasiswa yang supel dan pandai bergaul. Hal tersebut terlihat dari pergaulan di kampusnya. Meskipun bercadar, Wati memiliki teman-teman yang banyak, baik perempuan maupun pria. Cadar tidak menghambatnya bergaul dan berdiskusi dengan teman-temannya. Namun, Beliau yang telah merasakan dan melihat pergaulan remaja seusianya, berkesimpulan jika kehidupan remaja itu penuh dengan jebakan dosa. Banyak perbuatan remaja dalam persepsinya, jauh dari ajaran agama yang dianutnya, seperti: kenakalan remaja, narkoba, hingga seks bebas, menjadikan Wati menarik diri dari pusaran kehidupan remaja sebayanya.

Pengakuan senada juga disampaikan oleh Hany, bahwa kehidupan remaja mereka ternyata penuh dengan kehidupan yang menyimpang dari ajaran Islam yang mereka pahami sebelumnya. Kehidupan remaja di Surabaya yang mereka rasakan maupun mereka 
amati, menunjukkan gelagat yang menyimpang dari norma-norma yang mereka imani, bagi mereka menjadi muslim yang sejati adalah "melakukan segala sesuatu sesuai syariat".

Berdasarkan pengamatan terhadap halhal berikut, berangkat dari jawaban para responden, ditemukan bahwa tingkat keterlibatan mereka dalam bercadar, diakibatkan karena banyaknya ajakan dan tausiah tentang ayat-ayat yang mengharuskan perempuan untuk bercadar, sesuai dengan alquran dan hadit yang diberikan oleh penceramah dan buku-buku yang mereka baca dan dengar. Seperti pendapat Jeha, Dalam hadis Imam Ath Thabari menjelaskan: pendapat para ulama khalaf mengenai sifat menjulurkan Jilbab yang diperintahkan Allah dalam ayat ini, sebagai mereka mengatakan: yaitu dengan menutup aurat wajah-wajah mereka dan kepalakepala mereka, dan tidak ditampakkan apa-apa kecuali hanya satu mata saja. Cadar bagi semua Wati, Hany dan Jeha adalah ajaran syariah bersifat sunah, yang mampu menjaga mereka dari tindakan khalwat. Seperti pendapat salah seorang informan bernama Nur, sebagai berikut,

Tentu ada, setelah saya menggunakan cadar saya lebih bisa terjaga dari yang bukan mahram, tetapi sebelum saya menggunakan cadar saya merasa waswas dan merasa berdosa kepada diri saya ketika saya keluar rumah tanpa menggunakan cadar, lelaki bisa saja memandangi wajah saya dengan sesuka hatinya.

Keinginan bercadar, bukan untuk menunjukkan fanatisme tetapi sebagai upaya hijrah dan penjagaan diri terhadap pergaulan remaja yang bebas, sesuai apa yang mereka baca dan alami dalam pergaulan nyata di lingkungan mereka. Para responden memakai cadar ada yang sejak 10 tahun lalu, tetapi ada pula yang baru 10 bulan memakainya. Mereka semua berangkat dari argumen bahwa pergaulan remaja yang sangat bebas menyebabkan mereka memilih untuk bercadar. Seperti pendapat dari Sifa,

Bukan menjadi lebih sholehah dibanding yang lain, tetapi saya ingin menjadi lebih baik dari diri saya yang kemarin. Dengan cadar, ketika saya timbul niat untuk bermaksiat saya ingat dan saya lihat pakaian saya apakah saya pantas melakukan dan apakah saya tidak malu kepada Allah SWT.

Menarik pendapat Sifa, meskipun paling lama dalam bercadar, akan tetapi tidak kaku dengan modernitas, bahkan dia tak ragu untuk bergaya dalam berpakaian, karena baginya cadar bukan pembatasan terhadap modernitas, tetapi bagian dari modernitas itu sendiri. Keinginan untuk bercadar sebagai besar merupakan keinginan yang baru, karena direspons oleh situasi lingkungan yang telah digambarkan oleh hadit sebagai lingkungan yang buruk, seperti banyaknya kegiatan khalwat dan maksiat. Berkaitan dengan isu terorisme atau radikalisme, ditepis oleh mereka, karena pilihan bercadar tidak selalu berhubungan dengan ajaran kekerasan terhadap negara, atau ideologi anti negara.

Dari pengakuan mahasiswa yang tidak bercadar, bahwa mahasiswa bercadar adalah teman yang baik dan menyenangkan diajak bicara. Meskipun dalam praktiknya, setiap pembicaraan selalu dikembalikan kepada agama. Sepertinya mereka memandang bahwa semua orang ingin disadarkan kepada jalan yang benar, seperti pendapat Afi:

Menurut pengalaman saya, saat teman bercadar mengomentari sesuatu mereka cenderung selalu mengaitkan satu permasalahan dengan agama. Dengan kata lain, mereka selalu melihat satu fenomena namun tetap dari kacamata Islam.

Kesan baik dan Islami itulah yang ingin ditunjukkan oleh komunitas bercadar, bukan pada kesan radikal dan terorisnya. Namun, apa yang dikemukakan oleh Afi, berbeda dengan apa yang dirasakan dan dialami oleh Rina, yang menyatakan bahwa, "Tidak, karena menurut pengalaman dan yang saya lihat di lingkungan sekitar, kelakuan orang bercadar tidak lebih baik dari orang yang tidak bercadar". Ini membuktikan bahwa terkadang cadar lebih menunjukkan fashion ketimbang representasi suatu nilai keluhuran atau radikalisme.

Berdasarkan hasil observasi lapangan, mereka merupakan mahasiswa yang relatif supel, mudah bergaul dan cukup berprestasi di 
kelasnya. Ketertarikan mereka terhadap cadar, pada umunya berangkat dari pemahaman tentang cadar yang mereka dapatkan dari berbagai pengajian, bacaan dan posting media sosial yang mengajak untuk bercadar. Secara umum mereka menyandarkan argumen bercadarnya, seperti diungkapkan oleh Fifi:

Terdapat banyak tafsir hadis dan Alquran yang menjelaskan tentang bercadar; Q.S. Al-Ahzab: 59 dijelaskan bahwa "Hai Nabi katakanlah kepada istri-istrimu, anak-anak perempuan, istri-istri orang mukmin, hendaklah mereka menjulurkan jilbabnya ke seluruh tubuh mereka, yang demikian itu supaya mereka lebih mudah dikenal karena itu mereka tidak diganggu, dan Allah adalah Maha Pengampun dan Penyayang. Saya mendapatkan pelajaran tersebut dari media social; youtube, instagram, whatsapp, dan google. Setelah saya merasakan manfaatnya, saya merasa lebih terjaga apabila ingin bepergian. Sebelumnya saya ragu dan takut ketika berpapasan dengan orang-orang terutama kaum Adam (ikhwan). Lebih baik terhindar dari segala fitnah, karena alasan saya bercadar ingin menjaga diri dari keadaan lingkungan.

Sedangkan citra baru yang mereka dapatkan menjadikan diri mereka menjadi pribadi yang lebih baik dari sebelumnya, seperti pengakuan Fifi:

Sebelumnya saya hanyalah orang biasa yang penuh dengan kesalahan, saya adalah orang yang gampang marah, menangis dan agak tersinggung, tetapi ketika saya sudah bercadar saya merasa ada sesuatu hal yang menahan saya untuk tidak melakukan hal itu lagi, saya lebih bisa mengontrol diri, menurut saya pakaian seseorang bisa menutupi perilaku aslinya, tetapi jika seseorang yang benar-benar niat berubah ke jalan yang baik dan benar maka pakaian bisa sejalan dengan kesholehannya. Saya bukang orang yang merasa sholehah saya hanya berusaha untuk memperbaiki diri menjadi orang yang lebih baik dari sebelumnya, tingkat kesholehan hanya Alloh yang dapat mengukurnya.
Kekuatan lingkungan sangat dominan membentuk perilaku bercadar. Selain teman dan orang tua, kini media sosial dan grup Whatsapp (WAG) juga memberi kontribusi terhadap penanaman sebuah perilaku sosial. Ada komunikasi intensif di dalam WAG sehingga proses pertumbuhan suatu perilaku terus dipantau bahwa dijejalkan untuk tetap berkembang hingga membentuk menjadi kepribadiannya, seperti penjelasan dari Fifi yang lebih terbuka menjawabnya, sebagai berikut:

Saya punya teman yang mengajak saya untuk bercadar, karena menurut saya itu suatu hal yang baik. Dia sangat baik dan mengerti keadaan saya. Dia selalu memberi semangat agar saya kuat menghadapi semua masalah. Dia perkenalkan kepada saya apa itu cadar. Dia jelaskan kelebihan apa saja yang didapatkan ketika bercadar. Ketika dia tahu saya bercadar, dia bahagia mendengar hal tersebut dan dia selalu menyemangati saya. Dia memberi motivasi agar saya semakin kuat. Dia selalu memberi saya sebuah ucapan yang menyentuh, dengan mengatakan "tetap pertahankan, aku yakin kamu adalah orang yang kuat." Allah akan ada bersama kita. Itu yang membuat saya kuat.

\section{Fenomena Hijrah}

Cadar bagi semua responden diakui sebagai sarana hijrah, dan menguatkan suatu konsep diri yang lebih baik dari sebelumnya, seperti dikatakan informan berikut:

Alhamdulilah saya merasa menuju ke arah yang lebih baik dari sebelumnya, karna saya mempunyai banyak kesalahan dan perilaku yang kurang baik. Kini saya selalu menundukkan pandangan, bersikap ramah, rendah hati tidak sombong, dan selalu merasa dirinya harus berbenah menuju ke arah baik, bukannya riya merasa diri paling benar dan sholehah.

Jika merunut pada latar ideologi kontra negara, tampaknya semuanya mengakui jika negara Indonesia adalah negara yang mereka cintai. Sebagaimana pernyataan berikut "saya 
mencintai negara ini, karena negara ini adalah negara yang baik yang kental akan keislaman insya Allah semoga menjadi negara yang baik dan cinta akan perdamaian". Walaupun demikian, banyak orang yang salah memandang orang bercadar. Hal tersebut dirasakan oleh Rina, sebagai berikut.

Sebelum saya menggunakan cadar, kesan yang saya dapatkan dari keluarga dan lingkungan sekitar serta teman-teman saya masih bersikap biasa tetapi setelah saya menggunakan cadar respons dari keluarga sangat mengejutkan. Ada yang menolak untuk berteman dan lingkungan sekitar saya lebih mengerikan responsnya. Ada yang mengatakan saya seorang teroris, setan, isis dan lebih parahnya lagi mengatakan kalau saya penghuni neraka.

Hadirnya cadar pada kehidupan mereka terjadi karena ada persepsi baru tentang cadar, yakni cadar menjadi fungsi proteksi atas pergaulan bebasnya. Seperti pengakuan Nur, sebagai berikut.

Yang saya pahami tentang bercadar adalah pelindung. Bercadar adalah sunah, tapi lebih baik menghindari fitnah, dan juga zinnah dari lawan jenis. Manfaat yang saya dapatkan adalah saya lebih merasa dekat dengan Allah. Saya tidak banyak diganggu oleh laki-laki. Lebih terjaga dan terlindungi. Bagi saya sama saja, mau itu budaya Arab atau budaya Indonesia. Yang penting bagaimana kita selalu istiqomah dan selalu menjalankan yang menurut kita baik. Bagi saya itu saja alasan bercadar saya. Agar terlindung, merasa dekat sama Allah, dapat menjaga jarak, menjaga sikap, dan lain-lain.

Di kampus dan di luar kampus dapat disaksikan jika para mahasiswi pun memiliki sikap bercadar sesuai pakem dan mengikuti zaman. Dalam berpenampilan mereka tidak secara ketat bersyariah tetapi dengan mengalir mengikuti pergaulan dan modernisme dalam tampilan syariah. Menarik sekali pengakuan dari Hany, yang mengatakan jika cadar adalah simbol penjagaan diri dari fitnah, "karena menurut saya, cadar sebagai tameng untuk berlindung dan terlindung dari berbuat maksiat, menyelamatkan para ikhwan dari fitnah pandangan".

Hijrah atau beralih cara pandang dan bersikap, yang dilakukan oleh mahasiswi, membawa implikasi terhadap penguatan perilaku beragama mereka. Mereka semuanya terdorong untuk semakin masuk ke dalam ajaran lebih dalam lagi dari sebelumnya. Mereka mengaku merasakan dampak dari hijrah tersebut, yaitu lebih mendekatkan diri kepada Allah, menghargai hak-hak orang lain dalam beragama, lebih menjaga diri, dan lebih menundukkan pandangan.

Mereka memandang bahwa bercadar merupakan kehidupan yang diinginkan sebagai seorang muslimah. Hanya dengan berhijrahlah mereka dapat menata kehidupannya lebih syari dibanding sebelum-nya. Hijrah nyata bagi mereka adalah mengganti style berpakaian mereka sebelumnya menjadi bercadar. Karena itulah dorongan untuk menjadi suci (pureness) semakin mencuat sebagai sebuah kepentingan yang harus diperjuangkan, meskipun mendapatkan tantangan ketika mereka berada di ruang publik seperti kampus.

Cadar akhirnya menjadi ruang baru dalam membentuk perilaku baru. Bagi mereka cadar bukalah selembar pakaian, namun ruang imajiner tempat melekatnya semua norma agama. Dengan bercadar mereka semakin tenang untuk menerapkan ajaran Islam secara total. Salah seorang informan menyatakan sebagai berikut 'sebelum bercadar saya suka chatting dan kurang bisa membatasi diri; setelah bercadar, aktivitas saya serasa lebih positif misal pengajian, latihan panah, dan lainlain”.

\section{Fashion dan Kesesuaian Ruang (Space Queer)}

Style bercadar sebenarnya gaya berpakaian yang privasi bagi masyarakat Indonesia. Indonesia tidak memiliki gaya berpakaian dengan memakai cadar di ruang publik. Namun berbeda dengan hijab atau jilbab. Hijab sebagai fashion sudah banyak digunakan masyarakat muslim di Indonesia. Perkembangannya sangat pesat seiring perkembangan teknologi (Istiani, 2015). Melalui teknologi, trend dan gaya hijab berkembang ke dunia maya termasuk sosial 
media (Wulandari, 2016). Jilbab dan hijab tidak lagi sekedar simbol agama dan kesucian tetapi juga bergeser menjadi fashion yang modis (Suhendra, 2016).

Fenomena cadar di ruang publik seperti kampus, ruang kerja, kantor pemerintahan yang sifatnya tempat pelayanan publik, mendapat perhatian ekstra dari masyarakat awam. Mahasiswi yang bercadar di kampus, mendapat perhatian ekstra, baik dari sesama teman maupun institusi kampus. Atas reaksi penggunaan cadar di kampus, reaksi mahasiswi pun beraneka ragam. Di IAIN Bukit Tinggi para mahasiswi pengguna cadar memilih menggunakan masker sebagai pengganti cadar penuh. Salah satu dosen, bahkan melakukan perlawanan hukum atas keluarnya larangan bercadar pada dirinya.

Perselisihan terjadi sebenarnya karena adanya paham tentang ruang priv-pub (gabungan antara private dan public space). Para pemakai cadar, memandang semua ruang adalah tunggal untuk ekspresi agama, sehingga mereka merasa pemakaian cadar yang sifatnya private diumbar di ruang publik. Ruang privpub ini mengakibatnya persepsi baru pada pemakai cadar, yakni mereka dianggap streotype sebagai teroris atau bagian dari gerakan radikal. Seperti salah satu alasan dari peihak UIN Sunan Kalijaga mengeluarkan surat pembinaan bagi mahasiswi bercadar di UIN Sunan kalijaga, karena dianggap mereka bagian dari gerakan radikal.

Akibat tidak mampu memisahkan ruang private dan publik, terjadi keengganan para mahasiswi bercadar dan dosen untuk kompromi dengan peraturan pembelajaran. Mereka tidak berkenan membuka cadar pada proses pembelajar yang menuntut otentisitas wajah, seperti ketika ujian berlangsung. Sementara pihak universitas menerapkan aturan tidak boleh menutup wajah ketika ujian berlangsung. Ada pula mata pelajaran yang mengharuskan belajar tanpa menutup wajah sebagai prasyarat proses pembelajaran, misalnya prounauntion, dan lain sebagainya.

Keengganan mereka untuk membuka cadar, menyebabkan proses otentisitas formal pada saat memenuhi syarat administrasi terganggu. Hal ini terjadi akibat ketidakmampuan mereka memisahkan ruang publik dengan ruang private. Menyebabkan sikap tidak kompromi dari kampus.

\section{Analisis}

Pada kasus yang dibahas melalui tulisan ini, pilihan bercadar bukanlah suatu pilihan tanpa suatu dorongan. Dorongan tersebut membentuk struktur di balik kesadarannya, yakni struktur kesucian (structure of pureness). Berangkat dari persepsi bahwa kehidupan kota dengan pergaulan remaja yang keluar dari tuntunan syariah, menjadi pemicu sebuah kesadaran ingin keluar dari jeratan dosa. Structure of pureness ini semakin menguat oleh bentukan lingkungan serta informasi yang gencar mereka dapatkan dari media. Kehidupan kota dengan pergaulannya dikesankan sebagai kehidupan penuh dosa dan akan menjerumuskan mereka pada dosa besar, suatu beban kematian yang sulit mereka tanggung.

Dengan bertemunya para pencari kesucian diri, menjadikan ruang hidup structure of pureness semakin nyata. Tekanan apapun dari berbagai pihak dianggap sebagai tantangan sekaligus pembuktikan atas kesungguhan mereka terhadap sikap hijrahnya. Cemoohan dan tekan struktur kekuasaan dari yang anti cadar dianggap sebagai ruang uji atas ketangguhan mereka, walaupun ada di antara mereka yang tidak kuasa bernegosiasi dengan tekanan peraturan kampus dalam melarang sikap bercadar. Ketakutan tersebut pun, tetap saja disikapi dengan logika perlawanan tersembunyi, yakni dengan memakai masker. Selembar kain penutup mulut dan hidung dari debu. Dengan memodifikasi masker senada dengan warna pakaian, mereka menanggapnya sebagai cadar.

Pilihan masker merupakan pilihan politis yang dilakukan oleh para mahasiswi untuk menyiasati tekanan dan ancaman pihak kampus. Hal tersebut menjadi mereka memiliki alasan yang kuat untuk tetap menutup sebagian wajahnya, seperti bercadar, yakni karena alasan kesehatan, alergi debu atau sedang sakit influenza. Argumen tersebut sangat ampuh menjawab tekanan kampus untuk melepas tutup wajahnya. Hal ini merupakan solusi kreatif yang dikembangkan para mahasiswi. Hal yang serupa juga pernah dilakukan orang mahasiswi Mesir. Hijab bukan lagi dipahami sebagai 
bagian dari kepatuhan agama, tetapi sebagai bagian dari aksesoris kecantikan, sehingga di Mesir banyak perempuan eksekutif berhijab (MacLeod, 1992; 30). Hal inilah yang terjadi dalam logika mahasiswi yang bermasker, sebagai pengalihan dari bercadar karena menghadapi tekanan dari struktur hegemoni kampus. Masker bukan dianggap sebagai penutup debu, tetapi dianggap sebagai cadar.

Semangat yang tinggi ingin menerapkan cadar, di ruang di mana cadar tidak dianggap busana yang biasa dikenakan di ruang publik ini, menyebabkan para pemakai cadar mendapat streotype, stigma sebagai kelompok teroris atau radikalis agama. Tentu stigma sosial ini tidak dapat diterima oleh mahasiswi pemakai cadar. Karena semangat mereka memakai cadar lebih didorong oleh euphoria berbusana muslim, bukan karena terpapar ideologi radikal atau terorisme. Meskipun, stigma tersebut secara sosial mendapat pembenaran, karena para umumnya mahasiswi bercadar bertindak tidak kooperatif dengan peraturan di ruang publik. Mereka enggan membuka cadar dalam proser pembelajaran, seperti ujian semester atau mengurus administrasi, karena mereka berpandangan bahwa ruang publik harus mengikuti cara mereka dalam berpakaian serta menghormati hak mereka dalam berbusana.

Hal tersebut menjadi isu menarik untuk didiskusikan sebagai unsplited space, lahirnya ruang priv-pub, yakni mencampurkan ritual private tanpa menghormati ruang publik. Hal ini terjadi karena adanya anggapan bahwa ruang ibadah itu pada setiap ruang publik.

Dengan demikian, kesadaran atas adanya ruang publik semestinya menjadi kesadaran para mahasiswi bercadar, sehingga dapat menempatkan diri sesuai dengan peraturan yang berlaku sebagai tanda menghormati etika dan norma ruang publik itu sendiri. Hal ini bukan berarti membuka aurat atau jilbab ketika berada di ruang publik. Tetapi berkompromi menyesuaikan gaya jilbab sesuai dengan tuntutan dan fungsi ruang yang meminta wajah menjadi bagian dari otentisitas serta kapasitas keilmuannya.

Semangat untuk menjadi/merasa suci (structure of pureness) menjadi akar dari perubahan yang terjadi pada diri mahasiswi bercadar. Berubah dari kultur dosa menuju kultur suci. Proses migrasi atau hijrah atau pergeseran budaya (shifting culture) menjadi sesuatu yang tidak bisa dihindari.

Pada disisi lain, semangat untuk menjadi/merasa suci (structure of pureness) ini menjadi jembatan yang berbahaya. Dalam prosesnya mereka dapat terjebak oleh ajakan dan persuasi yang penuh dengan kepentingan sosial, politik, dan ekonomi berbalut bahasa agama. Para pencari kesucian ini memiliki semangat menggebu ingin segera menjadi suci. Sementara bentuk kesucian yang mereka tampilkan menjebak mereka bersikap dan berperilaku ekslusif, atau tanpa sadar terbawa pada pemikiran ekstrim dalam beragama serta melawan keteraturan negara.

Hal tersebut terjadi karena kelompok pencari kesucian ini membangun logika space queer, yakni suatu logika subjektif yang melegitimasi setiap ruang secara persepsional yakni arena penegakan syariah bagi dirinya. Mereka menuntut otoritas publik untuk membebaskan ekspresi privasi mereka secara optimum, tanpa mempedulikan tatanan publik yang selama ini kukuh dan kokoh mengatur ruang publik.

Space queer merupakan istilah Abraham (2007) mengenai adanya logika subjektif para pemakai cadar ketika mereka berada di ruang publik. Secara umum, ruang publik adalah tempat menampung aktivitas bersama masyarakat untuk meraih tujuan bersama yang dikelola dengan aturan bersama, termasuk kampus. Namun para pemakai cadar menjadikan ruang publik sebagai ruang ekspresi bahkan berusaha memaksa aturan publik menghargai ekspresi privasi mereka dalam bercadar. Bagi Abraham, nalar dibalik ekspresi dalam ruang tersebut merupakan space queer, yakni suatu ruang real yang dikonstruksikan sebagai ruang private berdasarkan nalar dan norma private.

\section{KESIMPULAN}

Dari penjelasan temuan dan analisis tersebut di atas, beberapa hal yang penting untuk disimpulkan bahwa perilaku berpakaian cadar mahasiswi didorong oleh semangat berubah atau hijrah untuk menjadi atau merasa suci (structure of pureness). Hal tersebut tumbuh sejak mereka menemukan kekecewaan 
terhadap tingkah laku remaja di sekitarnya yang jauh dari syariah. Untuk menghapus rasa berdosa, mereka memilih untuk melakukan perubahan budaya (cultural shifting) atau hijrah menuju sikap dan perilaku kesucian. Dasarnya adalah struktur kesucian, bukan struktur permusuhan anti negara. Jika dalam praktiknya, mereka tidak dapat berkompromi dengan aturan kampus, hal tersebut disebabkan karena mereka tidak dapat memilah antara ruang privat dan ruang publik. Strucuture of Pureness tampak kuat hadir dalam sikap resistensi dan tidak kompromi terhadap peraturan kampus. Mereka memiliki logika ruang yang unik, yakni semua ruang sebagai tempat penegakan syariah. Konsep kesesuaian ruang (space queer) tidak berlaku bagi mereka, atau tidak diterima.

\section{REKOMENDASI}

Berdasarkan kesimpulan di atas, maka beberapa rekomendasi yang relevan dan penting adalah sebagai berikut. Pertama, masyarakat dan pemerintah harus menghentikan stereotyping terhadap mahasiswi bercadar sebagai bagian dari jaringan teroris. Kedua, mengajarkan pendekatan taat dan tertib aturan, terutama dalam menerapkan aturan pada prosedur administrasi publik yang menuntut otentisitas diri (wajah).

Ketiga, Lembaga pendidikan dan kantor pemerintah atau layanan publik, perlu menjelaskan bahwa penolakan terhadap cadar atau hijab, bukan karena asosiasi dan pandangan terhadap mereka sebagai penganut ajaran radikal atau ekstrimis, tetapi lebih pada maksud positif yang berhubungan dengan syarat pembelajaran, pekerjaan, dan keamanan. Keempat, memberikan ruang gerak bagi tumbuh kembangnya ruang private dan moralitas publik bagi kalangan sivitas akademika, khususnya mahasiswa, karena mahasiswa bercadar juga memiliki prestasi dalam bidang akademik dan kegiatan kampus.

\section{UCAPAN TERMA KASIH}

Ucapan terima kasih disampaikan kepada Pusat Penelitian dan Pengembangan (Puslitbang) Pendidikan Agama dan Keagamaan Kementerian Agama RI, selaku sponsor penelitian ini. Kepada Amsal Bahtiar, selaku Pengarah Tim Peneliti atas nama Puslitbang Pendidikan Agama Kementerian
Agama RI, dan para peneliti, yang telah memberikan masukan dalam penyusunan desain dan pelaksanaan riset. Semoga kerja sama ini membawa manfaat yang besar bagi kemajuan bangsa dan kemajuan ilmu pengetahuan.

\section{DAFTAR PUSTAKA}

Abraham, I. (2007) 'The veil and the closet: Islam and the production of queer space', Queer Space: Centres And Peripheries, UTS, pp. 1-6.

Aulia, R. N. (2013) 'Rimpu: Budaya Dalam Dimensi Busana Bercadar Perempuan Bima', Jurnal Studi Al-Qur an.

Bourdieu, P. (1977) 'Outline of a of Practice'.

Cahyaningrum, D. R. and Desiningrum, D. R. (2017) 'Jiwa-Jiwa Tenang Bertabir Iman: Studi Fenomenologi Pada Mahasiswi Bercadar Di Universitas Negeri Umum Kota Yogyakarta', 7(3), pp. 278-296.

Fithrotin (2017) 'Cadar Wanita dalam Perspektif al-Qur'an', Madinah: Jurnal Studi Islam, 4(1).

Furseth, I. (2019) 'The Hijab : Boundary Work and Identity Negotiations Among Immigrant Muslim Women in The Los Angeles Area'. Linked references are available on JSTOR for this article: amount attention in the world, 52(4), pp. 365-385.

Gould, R. (2014) 'Feminist Theory contemporary Iran'. doi: $10.1177 / 1464700114544610$.

Haddad, Y. Y. (2019) 'The Post-9 / 11 Hijab as Icon *', 68(3), pp. 253-267.

Iskandar, A. S. (2013) 'Konstruksi identias muslimah bercadar', Artikel.

Istiani, A. N. (2015) 'Konstruksi Makna Hijab Fashion Bagi Moslem Fashion Blogger', Jurnal Kajian Komunikasi, 3(1), pp. 48-55.

Khosrojerdi, F. (2015) 'Muslim Female Students and Their Experiences of Higher Education in Canada Graduate Program in Education', (June), pp. 1220. 
MacLeod, A. E. (1992) 'Hegemonic Relations and Gender The New Veiling as Resistance: Protest in Cairo Accommodating', 17(3), pp. 533-557.

Prendergast, C. and Ebrary (1995) Cultural materialism: on Raymond Williams. doi: 10.5749/j.ctttspjc.

Proust, J. (2015) 'The Representational Structure of Feelings', 31. doi: 10.15502/9783958570047.

Ratri, L. (2011) 'Cadar, Media, dan Identitas Perempuan Muslim', Universitas Diponegoro, 39(02).

Shin, A. L. (2015) 'Muslim women and the veil : an experimental study of social bias'.

Shirazi, F. (2001) 'The Veil Unveiled: the Hijab in Modern Culture', (University of Florida Press), pp. 87-88.

Suhendra, A. (2016) 'Kontestasi Identitas Melalui Pergeseran Interpretasi Hijab dan Abstrak Jilbab Dalam Al Qur'an', PALASTREN Jurnal Studi Gender, 6(1), pp. 1-22.

Susanti, A. (2008) Gambaran Persahabatan dan Penyesuaian Diri pada Mahasiswi UIN Jakarta yang Mengenakan Cadar. Universitas Islam Negeri Syarif Hidayatullah.

Todd, S. (1998) "Veiling the " Other ," Unveiling Our "Selves": Reading Media Images of the Hijab Psychoanalytically to Move beyond Tolerance Author (s): Sharon Todd Published by: Canadian Society for the Study of Education Stable URL: http://www.jstor.org/ stable/15, Canadian Journal Of Education, 23(4), pp. 438-451.
Wardhani, F. Y. (2008) 'Permasalahan dan Penyesuaian Diri pada Pernikahan Muslimah Berhijab dan Bercadar', Anima Indonesian Psychological Journal, 23(3), pp. 227-236.

William, R. (1960) 'Culture and society , 17801950', book, (A Dobbleday achoror Book, Garden City, New York), p. 412.

William, R. (1977) 'Marxism and Literature'.

Williams, R. H. and Vashi, G. (2007) 'Hijab and American Muslim women: Creating the space for autonomous selves', Sociology of Religion: A Quarterly Review, 68(3), pp. 269-287. doi: 10.1093/socrel/68.3.269.

Wulandari, E. N. (2016) Popularitas Fashion Hijab Melalui Akun Instagram@ Hijabercommunityofficial. UIN Syarif Hidayatullah. Available at: http://repository.uinjkt.ac.id/dspace/han dle/123456789/32329.

Zahedi, A. (2007) 'Contested Meaning of the Veil and Political Ideologies of Iranian Regimes', Journal of Middle East Women's Studies. doi: 10.2979/mew.2007.3.3.75 